\title{
Expression of functional recombinant human factor IX in milk of mice
}

\author{
Sharon F. C. Lisauskas - Nicolau B. Cunha - Giovanni R. Vianna • \\ Érica A. Mendes · Gustavo L. Ramos · Andréia Q. Maranhão • \\ Marcelo M. Brígido · Jussara O. S. C. Almeida · Heloisa A. Baptista • \\ Fabiana L. T. Motta · João B. Pesquero · Francisco J. L. Aragão · \\ Elíbio L. Rech
}

Received: 18 June 2008/Revised: 18 July 2008/Accepted: 21 July 2008/Published online: 8 August 2008

(C) Springer Science+Business Media B.V. 2008

\begin{abstract}
Human factor IX is synthesized in the liver and secreted in the blood, where it participates in a group of reactions involving coagulation factors and proteins that permit sanguinary coagulation. In this work two lines of transgenic mice were developed to express the $F I X$ gene in the mammalian glands under control of milk $\beta$-casein promoter. The founding females secreted the FIX in their milk (3\% total soluble protein). The stable integration of transgene was confirmed by southern blot analysis. The presence of the FIX recombinant protein in the milk of transgenic females was confirmed by western blot and the clotting activity was revealed in
\end{abstract}

S. F. C. Lisauskas - N. B. Cunha - G. R. Vianna ·

É. A. Mendes · G. L. Ramos · F. J. L. Aragão ·

E. L. Rech $(\square)$

Embrapa Recursos Genéticos e Biotecnologia, Parque

Estação Biológica, PqEB, Av. W5 Norte (final), Brasilia, DF CEP 70770-900, Brazil

e-mail: rech@cenargen.embrapa.br

S. F. C. Lisauskas - N. B. Cunha - G. L. Ramos ·

A. Q. Maranhão · M. M. Brígido

Departamento de Biologia Celular, Universidade de

Brasília, Brasilia, DF CEP 70910-900, Brazil

J. O. S. C. Almeida

Hospital de Apoio de Brasília, SGAIN, Quadra 04, Lote 04, Asa Norte, Brasilia, DF CEP 70.620-000, Brazil

H. A. Baptista · F. L. T. Motta · J. B. Pesquero Universidade Federal de São Paulo - UNIFESP Pro-Reitoria de Extensão - PROEX - Rua Pedro de Toledo, 957, Vila Clementino, São Paulo, SP CEP 04023-062, Brazil blood-clotting assays. The coagulation activity in human blood treated with recombinant FIX increased while the time of coagulation decreased. Our results confirm the production of a large amount of recombinant biologically active FIX in the mammary gland of transgenic mice.

Keywords Expression .

Recombinant human factor IX - Transgenic mice

\section{Introduction}

Hemophilia B or Christmas disease is a recessive $\mathrm{X}$-linked disease characterized by abnormal production of human coagulation factor IX. In Brazil there is an estimated incidence of 1 in 8,000 born, and $15 \%$ of these have hemophilia B. Human factor IX is a $55 \mathrm{kDa}$ single chain vitamin K-dependent plasma zymogen which has a serine protease function and plays a key role in the intrinsic coagulation pathway. This pathway is a series of enzyme-mediated cleavages by means of plasma factors of peptide chain fragmentation. Upon activation of FIX to FIXa by FXIa, an $11 \mathrm{kDa}$ activation peptide is removed from factor IX molecule by cleavage of two peptide bonds. These changes allow the activation of factor IX and are crucial to prothrombin and fibrinogen production and blood clotting (Di Scipio et al. 1978).

Factor IX is synthesized in the liver's parenchymal cells and requires a posttranslational vitamin K-dependent modification in order to work 
appropriately. Benefix, a recombinant FIX purified from transgenic chinese hamsters ovary cells, was the first recombinant drug successfully destined to hemophilia B treatment and demonstrated to be stable and safe both in vitro and under clinical conditions (Chowdary et al. 2001).

Besides this important effort, Christmas disease treatment by injection of either recombinant or purified FIX from human healthy donors' plasma (the most usual treatment form), still incurs on heavy costs and prion and virus contamination risks. Besides, human-derivate factors are unstable and require frequent injections. Today, Brazil is totally dependent on the importation of human factor IX molecule from pooled plasma.

Transgenic animals are indicated as potential successful bioreactors for complex heterologous protein biosynthesis, such as FIX, since high yields of protein and structural quality are generally associated with those systems (Houdebine 1994; Wall 1996). Another advantage of alternative based production of recombinant drugs in transgenic mammals is the ability to provide post-translational modifications correctly, which allows folding assembles and glycosilation similar to those present in humans (Larrick and Thomas 2001). The mammary gland can currently be considered one of the most efficient bioreactors (Colman 1996; Rudolph 1999). Extensive studies have demonstrated the possibility of the production of a great variety of recombinant proteins in milk, many of them complex proteins, such as: human IGFI (Zinoveiva et al. 1998), hGH (Devinoy et al. 1994), human lysozime (Lee et al. 1998), human lactoferrine (Platenburg et al. 1994), human erythropoietin (Sohn et al. 1999), human parathyroid hormone (Rokkones et al. 1996), recombinant factor VIII in milk of transgenic rabbit (Chrenek et al. 2007). These examples demonstrate the capacity of the mammary gland to synthesize, to mature and to secrete active biologically recombinant proteins.

Transgenic mice lines are attractive because of a series of advantages like the shortest reproduction cycle even when compared to other mammals, fast female lactation, high milk protein content and the relatively lower costs of maintaining the animals. Moreover, this model system will make future applicability possible in large animals, such as cattle and goats, used as efficient bioreactors. In the present work we report the expression of human coagulation factor
IX in transgenic mice milk and the evaluation of independent line level expression and biological function of the recombinant molecule. For human FIX expression in transgenic mice, the protein coding sequence was flanked by the $\beta$-casein promoter, a strong mammary gland tissue-specific regulatory sequence and microinjected in mice pronuclei.

\section{Material and methods}

Human factor IX expression vector

The code region of the FIX (coding for the human factor IX) gene (GeneBank accession number: XM010270) (Yoshitake et al. 1985) was amplified by PCR from a cDNA library ( $\lambda$ TriplEx, Clontech, USA) from human liver. The fragments were cloned into the pGEM-T Easy (Promega, USA) vector for PCR products. Primer pair BCproFIX [5'-GCTCGAGATGGCAAAGGTCCTCATCCTTGCCTGCCTGGTGGCTCTGGCCCTTGCAACAGTTTTTCTTGA TCATGAAA- $3^{\prime}$; including the sites for XhoI [underlined] and the sequence of the secretion signal of the bovine beta-casein (in bold)] and FIXstop3C [5'CCTTCTCGAGCCATCTTTCATTAAGTGAGC- ${ }^{\prime}$; including the sites for $\mathrm{XhoI}$ (underlined)] was used to amplify a 1,378-bp fragment from the FIX gene. PCR reactions were carried out in a thermocycler in $50 \mu \mathrm{l}$ containing $10 \mathrm{ng}$ DNA, $60 \mathrm{mM}$ Tris/ $\mathrm{H}_{2} \mathrm{SO}_{4}(\mathrm{pH}$ 8.9), $18 \mathrm{mM}\left(\mathrm{NH}_{4}\right)_{2} \mathrm{SO}_{4}, 2 \mathrm{mM} \mathrm{MgSO} 4,250 \mathrm{nM}$ each dNTP, $200 \mathrm{nM}$ each primer, and $5 \mathrm{U}$ of platinum Taq DNA polymerase high fidelity (Invitrogen, USA). The mixture was treated at $95^{\circ} \mathrm{C}(5 \mathrm{~min})$ and subjected to 35 cycles of amplification $\left(95^{\circ} \mathrm{C} / 1 \mathrm{~min}, 55^{\circ} \mathrm{C} / 1 \mathrm{~min}\right.$, and $68^{\circ} \mathrm{C} / 1 \mathrm{~min}$ ), with a final elongation cycle of $5 \mathrm{~min}$ at $68^{\circ} \mathrm{C}$. PCR products were sequenced by using universal M13 and T7 primers on automatic sequencer (ABI Prism1 3700). The 1,378-bp fragment from the FIX gene was cloned into the $X h o$ I restriction site of the pBC1 mammalian expression vector (Invitrogen, USA) to generate the vector pBC1FIX, which was used for pronuclear microinjection.

DNA preparation for generation

of transgenic mice

The plasmid pBC1FIX was digested with SalI and Not I to eliminate the prokaryotic ampicilin sequence. 
The fragment containing the FIX sequence was separated by $0.8 \%$ agarose gel electrophoresis and purified from gel with Qiaex II gel extraction kit (Qiagen, USA). The elution of DNA from the column was carried out with microinjection buffer (MIB$8 \mathrm{mM}$ Tris $/ \mathrm{HCl}, \mathrm{pH}$ 7.4, containing $0.15 \mathrm{mM}$ EDTA). The concentration was adjusted to $3 \mathrm{ng} / \mu \mathrm{l}$ in MIB, and used for production of transgenic mice. All animal manipulation and surgical procedures were carried out at Embrapa Recursos Genéticos e Biotecnologia, Hospital de Apoio de Brasília and Universidade Federal de São Paulo in accordance with the ethical standards of the institutional committees and the Helsinki Declaration.

\section{Superovulation}

B6CBAF1 female mice (4-5 weeks old) were superovulated by intraperitoneal (i.p.) injection of $5 \mathrm{IU}$ pregnant mare's serum gonadotrophin (PMSGSigma, USA). Approximately 48 h later, 5 IU human chorionic gonadotropin (hCG-Sigma, USA) were administered, also by i.p. injection, and coupled overnight with B6CBAF1 male mice.

\section{Collection of zygotes}

The pronuclear-stage embryos were collected $20 \mathrm{~h}$ after the hCG injection. The cumulus cells were removed by placing the zygotes in M2 medium (Sigma, USA) complemented with hyaluronidase $(0.1 \% \mathrm{w} / \mathrm{v})$ (Sigma, USA) for $2 \mathrm{~min}$. The embryos were washed several times in pure M2 medium to remove hyaluronidase and were maintained in M16 culture medium (Sigma, USA) at $37^{\circ} \mathrm{C}$ under $5 \% \mathrm{CO}_{2}$ until microinjection.

\section{Pronuclear microinjection}

Approximately 3 picolitre of exogenous DNA solution was injected into one of the pronuclei with the aid of a pair of manipulators at a $400 \times$ magnification, in an inverted microscope with Normarski differential interference contrast optics. The injection took place in a small drop of M2 medium covered by mineral oil (Sigma, USA) as previously reported (Chrenek et al. 2007). After that, the surviving embryos returned to M16 medium in the $\mathrm{CO}_{2}$ incubator.
Embryo transfer

Microinjected embryos (15 to 30 zygotes per foster mother) were transferred into the oviduct of pseudopregnant (Swiss) females on the day of microinjection. The pseudopregnancy of females was induced by mating with vasectomized (Swiss) males (Chrenek et al. 2007).

PCR analysis

Genomic DNA was purified using the commercial Wizard Genomic DNA Purification kit (Promega, USA) and used as a template in the reactions containing specific primers that pared with the internal sequence of the human factor IX gene. Primer sequences FIXAL256: 5'-GATGGAGATCAGTGTGAGTC- $3^{\prime}$ and FIXAL 751c: $5^{\prime}$-TAACGATAGAGCCTCCACAG- ${ }^{\prime}$ were utilized to amplify a $495 \mathrm{bp}$ sequence. DNA was subjected to 35 cycles of amplification $\left(94^{\circ} \mathrm{C} / 2 \mathrm{~min}, 94^{\circ} \mathrm{C} / 1 \mathrm{~min}\right.$, $58^{\circ} \mathrm{C} / 1 \mathrm{~min}, 72^{\circ} \mathrm{C} / 1 \mathrm{~min}$ and $72^{\circ} \mathrm{C} / 7 \mathrm{~min}$ ) carried out in $25 \mu \mathrm{l}$ aliquots containing $10 \mathrm{mM}$ Tris/ $\mathrm{HCl}$ (pH 8.4); $50 \mathrm{mM} \mathrm{KCl} ; 2 \mathrm{mM} \mathrm{MgCl}_{2} ; 160 \mu \mathrm{M}$ each dNTP; $2 \mu \mathrm{M}$ each primer; $2 \mathrm{U}$ Taq polymerase (Invitrogen, USA) and 20 ng genomic DNA.

\section{Recovery and total protein extraction}

Milk samples were taken from lactating transgenic and non-transgenic female mice on day 7 of first lactation. In order to stimulate let-down of milk, an intramuscular injection of $5 \mathrm{IU}$ oxytocin (Sigma, USA) was applied $30 \mathrm{~min}$ before milk collection. The samples were either subjected to further analysis or stored at $-80^{\circ} \mathrm{C}$ until used.

Recombinant protein extraction from the milk of the transgenic and non-transgenic animals was carried out by homogenization $1: 1(\mathrm{v} / \mathrm{v})$ in extraction buffer $\left(\mathrm{NaH}_{2} \mathrm{PO}_{4} 50 \mathrm{mM}, \mathrm{NaCl} 20 \mathrm{mM}\right.$, PMSF $2 \mathrm{mM}$ and DTT $10 \mathrm{mM}, \mathrm{pH} 7.5)$ for $1 \mathrm{~h}$ at $4^{\circ} \mathrm{C}$, followed by centrifugation $(5,000 \mathrm{~g}$ for $20 \mathrm{~min}$ at $4^{\circ} \mathrm{C}$ ) and the upper lipid layer and the supernatant removed. Total protein quantification was carried out by the Bradford method.

Southern blot analysis

Genomic DNA $(15 \mu \mathrm{g})$ isolated using Wizard Genomic DNA Purification kit (Promega, USA) was 
digested with KpnI (100 units), separated on 1\% agarose gel and transferred to a nylon membrane (Hybond $\mathrm{N}^{+}$). The hybridization was carried out using the PCR-generated 510 bp FIX probe, labeled with $\alpha\left[{ }^{32} \mathrm{P}\right]$-dCTP $(110 \mathrm{TBq} / \mathrm{mol})$ using a random primer DNA labeling kit (Pharmacia Biotech, USA) according to the manufacturer's instructions.

\section{Western blot analysis}

Total protein $(60 \mu \mathrm{g})$ was extracted from transgenic mice milk and $350 \mathrm{ng}$ human factor IX (Sigma, USA) were resolved in a $12 \%(\mathrm{v} / \mathrm{v})$ SDS-PAGE mini gel, electrotransferred to Hybond $\mathrm{N}^{+}$nitrocellulose membrane (Hybond) under $100 \mathrm{~mA}$ for $50 \mathrm{~min}$, followed by $4^{\circ} \mathrm{C}$ overnight blocking in Tristy buffered saline solution (20 mM Tris base, $137 \mathrm{mM} \mathrm{NaCl}, \mathrm{pH} 7.6$ ) containing 5\% (v/v) dry milk and $0.1 \%$ Tween 20.

The membrane was incubated with rabbit igG policlonal anti-human factor IX diluted 1:2,500 in blocking buffer, for $4 \mathrm{~h}$ at $25^{\circ} \mathrm{C}$. Secondary antibody incubation was performed for $3 \mathrm{~h}$ at $25^{\circ} \mathrm{C}$ with goat anti-rabbit igG conjugated with alkaline phosphatase (Bio-Rad) in a dilution of 1: 5,000 in blocking buffer. Alkaline phosphatase activity was monitored by $10 \mathrm{ml}$ detection buffer consisting of $100 \mathrm{mM}$ Tris/ $\mathrm{HCl} \mathrm{pH} 9.5,100 \mathrm{mM} \mathrm{NaCl}, 5 \mathrm{mM} \mathrm{MgCl}_{2}, 66 \mu \mathrm{l}$ NBT $50 \mathrm{mg} / \mathrm{ml}$ (Nitro blue tetrazolium) and $33 \mu \mathrm{l}$ BCIP $25 \mathrm{mg} / \mathrm{ml}$ (5-bromo-4cloro-3-indolil phosphate). Reaction was stopped by Tris/EDTA $20 \mathrm{mM}$ and the colored product was detected.

\section{Bioactivity assay}

The functional activity of FIX in mice milk samples was determined by assaying its ability to restore clotting activity using FIX-depleted human plasma together with the respective lacking factor. The partial thromboplastin time was interpreted using a reference curve obtained with dilutions of standard human plasma or a normal plasma pool mixed with the deficient plasma.

The samples (transgenic mice milk and nontransgenic mice milk) were diluted to $160 \mathrm{pg} / \mu \mathrm{l}$ of factor IX. $100 \mu \mathrm{l}$ each diluted milk sample was added in $100 \mu \mathrm{l}$ of factor IX-deficient plasma plus $100 \mu \mathrm{l}$ activated cephalin. After $5 \mathrm{~min}$ of incubation at $37^{\circ} \mathrm{C}$, $100 \mu \mathrm{l} 0.025 \mathrm{M} \mathrm{CaCl}_{2}$ was added, and the coagulation time determined.

\section{Results}

Transgenic mice

$\mathrm{F}_{2}$ Hybrid zygotes produced by mating male and female $\mathrm{F}_{1}$-hybrids (B6CBAF1) were microinjected with pBC1FIX vector and yielded thirty-four litters. PCR and southern blot analysis revealed two transgenic founders. The transgenic male founder was responsible for the continuity of line 1 , and the transgenic female founder for line 2 . In order to generate the progeny of these transgenic animals, the male and the female founders were mated with wild type animals of the $\mathrm{C} 57 \mathrm{bl} / 6$ strain. As a result, 13 animals were generated on the $F_{1}$ generation, 9 animals from line 1, and 4 from line $2 . \mathrm{F}_{1}$ progeny was submitted to PCR analysis, and the positive females were mated with male wild type mice for the attainment of the $F_{2}$ generation. Seven days after birth of the $F_{2}$ generation, the milk of the founders and $F_{1}$ female mothers was collected in order to analyze the FIX recombinant protein expressed in their milk.

PCR analysis (Fig. 1) revealed the presence of a 495-bp fragment from the factor $I X$ transgene coding
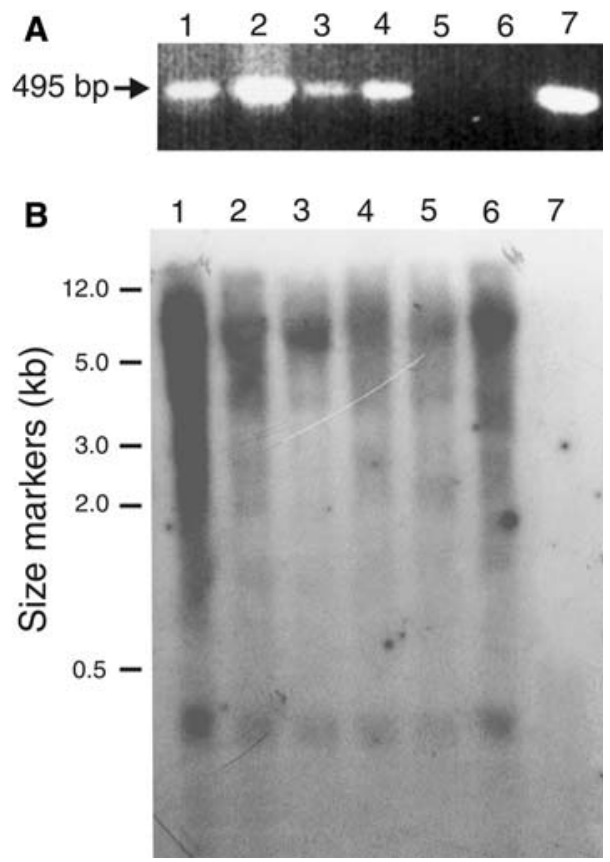

Fig. 1 (a) PCR screening of transgenic mice for the presence of the internal sequence of the human factor IX gene. Lanes 1, 2, 3 and 4: transgenic mice; Lane 5: non-transgenic mice; Lane 6: internal negative control; Lane 7 Plasmid vector. (b) Southern blot analysis of transgenic animal lines. Lanes 1 to 6 : transgenic mice; Lane 7: non-transgenic animal 


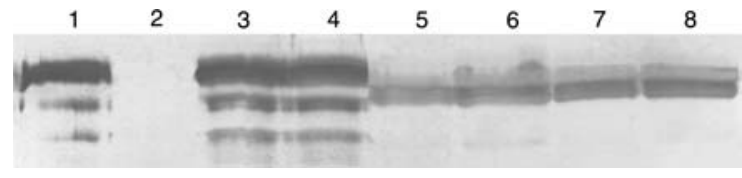

Fig. 2 Western blot for detection of FIX in the milk samples from transgenic mice females expressing the human factor IX gene. Lane 1: $350 \mathrm{ng}$ of purified FIX protein (Sigma, USA); Lane 2: $100 \mu \mathrm{g}$ total milk protein of non-transgenic female; Lanes 3 and 4:100 $\mu \mathrm{g}$ of transgenic founders lines 1 and 2; Lanes 5 and 6: $100 \mu \mathrm{g}$ of $F_{1}$ progeny from line 1; Lanes 7 and 8: $100 \mu \mathrm{g}$ of $F_{1}$ progeny from line 2

in both mice founders and progenies. Southern blot analysis confirmed the integration of the FIX transgene (Fig. 1). DNA isolated from a non-transgenic line did not hybridize with the $F I X$ cassette probe.

\section{Western blot analysis}

In milk samples obtained at day 7 from two lactating females from distinct lines, a band corresponding to $50 \mathrm{kDa}$ was detected by western blot analysis. This signal was not detected in non-transgenic milk (Fig. 2).

Functional activity of FIX in mice milk

Bioactivity assay was performed in order to detect the activity of FIX recombinant protein in percentage rate of its clotting action. It was found that a high level of concentrated active protein was encountered per microliter in mice milk. Milk of transgenic founder line $1\left(\mathrm{~F}_{0}\right)$, milk of transgenic founder line 2 $\left(\mathrm{F}_{0}\right)$, normal human plasma, hemophilic plasma supplemented with $100 \mathrm{pg} / \mu \mathrm{l}$ purified FIX from human plasma (Sigma, USA) and milk of nontransgenic female were evaluated. The coagulation activity detected by percentage was 1.7, 3.1, 100, 0.7 and 0 , and the time of coagulation was confirmed at 76, 69, 37.6, 87 and $141 \mathrm{~s}$, respectively (Table 1).

\section{Discussion}

Transgenic animals are capable of producing biologically active recombinant proteins at high levels. With the use of the expression vector $\mathrm{pBC} 1$, specific for the genetic transformation of mammal cells, the recombinant proteins are secreted at high levels in the
Table 1 FIX recombinant coagulation activities in the milk of transgenic and non-transgenic mice

\begin{tabular}{|c|c|c|c|}
\hline \multirow[t]{2}{*}{ Samples } & \multicolumn{3}{|l|}{ Method } \\
\hline & $\begin{array}{l}\text { Western } \\
\text { blot }\end{array}$ & $\begin{array}{l}\text { Coagulation } \\
\text { activity }(\%)\end{array}$ & $\begin{array}{l}\text { Thromboplastin } \\
\text { time (s) }\end{array}$ \\
\hline $\begin{array}{l}\text { Milk of transgenic } \\
\text { founder line } 1 \\
\left(\mathrm{~F}_{0}\right)\end{array}$ & + & 1.7 & 76 \\
\hline $\begin{array}{l}\text { Milk of transgenic } \\
\text { founder line } 2 \\
\left(\mathrm{~F}_{0}\right)\end{array}$ & + & 3.1 & 69 \\
\hline $\begin{array}{l}\text { Normal human } \\
\text { plasma }\end{array}$ & + & 100 & 37.6 \\
\hline 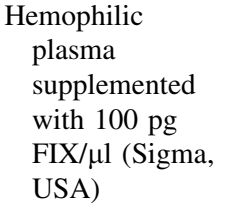 & + & 0.7 & 87 \\
\hline $\begin{array}{l}\text { Milk of non- } \\
\text { transgenic } \\
\text { female }\end{array}$ & - & 0 & 141 \\
\hline
\end{tabular}

transgenic animal's milk. Based on this, our constructed expression vector is an integrative vector that confers stable integration on the host genome and expression of recombinant protein in the milk of transgenic animals detected by southern blot, western blot and bioactivity analysis.

We used the microinjection method to produce transgenic mice. It is the most efficient technology used in generation of transgenic mice for gene addition (Watanabe et al. 2007) compared with other systems (Huszar et al. 1985; Jahner et al. 1985; Lavitrano et al. 1989). Our transgene integration efficiency was $6 \%$ considering the presence of two founders in 34 litters born. However, this technique has proven to be far less efficient in farm animals (Wall 2001). Since this technique results in randomly inserted transgenes, transgenic mice were screened by PCR and confirmed by southern blot analysis in order to evaluate the presence of the transgene introduced in the founders as well as in the progeny. We have studied transgenic integration in bovine cells (Lisauskas et al. 2007) to carry out gene-target integration to produce desired recombinant protein expression levels instead of randomly integrated and variable expression.

Our results showed that the amount of recombinant polypeptide secreted by mammary gland cells of 
founder 2 reached up to $2 \%$ of total soluble milk protein content (data not shown), which indicates a satisfactory expression level modulated by the betacasein promoter. Korhonen et al. (1997) generated several transgenic mouse lines and rabbits expressing human erythropoietin efficiently in their milk (up to $0.3 \mathrm{mg} / \mathrm{ml}$ in mice and up to $0.5 \mathrm{mg} / \mathrm{ml}$ in rabbits) with bovine beta-lactoglobulin as promoter.

Western blot results suggest the maintenance of the correct molecular mass of secreted FIX presented in both founders and $F_{1}$ females' milk; they also demonstrate the efficiency of the secretion strategy provided by the beta-casein secretion signal. Three band patterns presented by SIGMA's plasma purified FIX and recombinant mice FIX probably reflect the activation of FIX into FIXa by the cleavage of two peptide bonds of the $55 \mathrm{kDa}$ single chain (upper band), releasing the FIX $44 \mathrm{kDa}$ heavier chain (intermediate band) and the $11 \mathrm{kDa}$ light chain (lower band). The high concentration in mice milk of vitamin $\mathrm{K}$, which is important in effecting coagulation, corroborates the hypothesis of correct activation of FIX zymogen, correlated to western blot band pattern and further proof by coagulation bioassay.

In our study, to prove the efficiency of the FIX recombinant protein activity further, bioassays were performed with purified recombinant protein from transgenic mice milk. Activity of the recombinant coagulation factor IX protein was observed in its coagulant action, demonstrating the protein's function produced in heterologous system. Milk of transgenic founder line 1, transgenic founder line 2 , normal human plasma, hemophilic plasma and milk of non-transgenic female were compared. The activity of the protein was detected in percentage rate of its clotting action. It was found that a high level of concentrated active protein was encountered per $\mu \mathrm{l}$ in mice milk.

Transgenic technology is especially attractive for the recombinant protein production necessary on a large scale, due to units of required dosages, multiple administration, application in the population on a large scale, or need for industrial production. The annual market of large-scale recombinant proteins, plasma factors VIII and IX, is approximately 5-10 kg. In accordance with the World Federation of Hemophilia (Montreal, Canada), the cost incurred in supplying the current need for factor IX is approximately US\$190 million in the United States. For factor VIII, this cost is approximately US\$ 2 billion. The potential market for these products has been limited for the plasma supplement.

The final stage of the process that consists of the purification of recombinant proteins from milk generally does not present particular difficulties. Among the possible biological contaminants, the prions are the main constrain. However, evidence from the World Health Organization emphasizes that prions have not been detected in association with milk and semen, when closed herds are prioritized (Rudolph 1995; Gavin 2001). This work will form the foundation for the production of transgenic goats and cattle expressing recombinant human factor IX in the milk.

Acknowledgements The authors are grateful to Tatiana Lozada Medeiros and Ana Luisa Santa Cruz de Almeida for technical assistance. This study was supported in part by Empresa Brasileira de Pesquisa Agropecuária (Embrapa), Hospital de Apoio de Brasília, where the clotting action for protein was performed, Universidade Federal de São Paulo, $\mathrm{CNPq}$ and the International Hemophilia Training CenterWorld Federation of Hemophilia. S.F.C.L. was supported by a fellowship from CNPq.

\section{References}

Chowdary P, Dasani H, Jones JAH, Loran CM, Eldridge A, Hughes S, Collins PW (2001) Recombinant factor IX (BeneFix) by adjusted continuous infusion: a study of stability, sterility and clinical experience. Haemophilia 7:140-145

Chrenek P, Ryban L, Vetr H, Makarevich AV, Uhrin P, Paleyanda RK, Binder BR (2007) Expression of recombinant human factor VIII in milk of several generations of transgenic rabbits. Transgenic Res 16:353-361

Colman A (1996) Production of proteins in the milk of transgenic livestock: problems, solutions, and successes. Am J Nutr 63:639-645

Devinoy E, Thérot D, Stinnakre MG, Fontaine ML, Grabowski H, Puissant C (1994) High level production of human growth hormone in the milk of transgenic mice: the upstream region of rabbit whey acidic protein (WAP) gene targets transgene expression to the mammary gland. Transgenic Res 3:79-89

Di Scipio RG, Kurachi K, Davie EW (1978) Activation of human factor IX (Christmas factor). J Clin Invest 61: $1528-1538$

Gavin WG (2001) The future of transgenics. Regulatory Affairs Focus 13-18

Houdebine LM (1994) Production of pharmaceutical proteins from transgenic animals. J Biotechnol 34:269-287

Huszar D, Balling R, Kothary R, Magli MC, Hozumi N, Rossant J, Bernstein A (1985) Insertion of a bacterial gene 
into the mouse germ line using an infectious retrovirus vector. Proc Natl Acad Sci USA 82:8587-8591

Jahner D, Haase K, Mulligan R, Jaenisch R (1985) Insertion of the bacterial gpt gene into the germ line of mice by retroviral infection. Proc Natl Acad Sci USA 82:6927-6931

Korhonen VP, Tolvanen M, Hyttinen JM, Uusi-Oukari Mikko, Sinervirta R, Alhonen L, Jauhiainen M, Jänne OA, Jänne J (1997) Expression of Bovine $\beta$-Lactoglobulin/Human Erythropoietin Fusion Protein in the Milk of Transgenic Mice and Rabbits. Eur J Biochem 245(2):482-489

Larrick JW, Thomas DW (2001) Producing proteins in transgenic plants and animals. Curr Opin Biotechnol 12:411418

Lavitrano M, Camaioni A, Fazio VM, Dolci S, Farace MG, Spadafora C (1989) Sperm cells as vectors for introducing foreign DNA into eggs: genetic transformation of mice. Cell 57:717-723

Lee WK, Kim SJ, Lee T, Han Y, Yoo OJ, Im KS, Lee K (1998) Expression of a bovine beta-casein/human lysozyme fusion gene in the mammary gland of transgenic mice. J Biochem Mol Biol 31:413-417

Lisauskas SFC, Rech EL, Aragão FJL (2007) Characterization of transgene integration loci in transformed Madin Darby bovine kidney cells. Cloning Stem Cells 9:456-460

Platenburg GJ, Kootwiijk EP, Kooiman PM, Woloshuk SL, Nuijens JH, Krimperfort PJ (1994) Expression of human lactoferrin in the milk of transgenic mice. Transgenic Res 3:99-108

Rokkones E, Fromm SHO, Kareem BN, Klungland H, Olstad OK, Hogset A (1996) Human parathyroid hormone as a secretory peptide in milk of transgenic mice. J Cell Biochem 59:168-176

Rudolph NS (1995) Regulatory issues relating to protein production in transgenic animal milk. Gen Engine News 15:16-18

Rudolph NS (1999) Biopharmaceutical production in transgenic livestock. Trends Biotechnol 17:367-374

Sohn BH, Kim SJ, Park H, Lee SC, Hong HJ (1999) Expression and characterization of bioactive human thrombopoietin in the milk of transgenic mice. DNA Cell Biol 18:845-852

Wall RJ (1996) Transgenic livestock: progress and prospects for the future. Theriogenology 45:57-68

Wall RJ (2001) Pronuclear microinjection. Cloning Stem Cells 3:209-220

Watanabe M, Umeyama K, Kawano H, Izuno N, Nagashima H, Miki K (2007) The production of a diabetic mouse using constructs encoding porcine insulin promoter-driven mutant human hepatocyte nuclear factor- $1 \alpha$. J Reprod Dev 53:189-200

Yoshitake S, Schach BG, Foster DC, Davie EW, Kurachi K (1985) Nucleotide sequence of the gene for Human Factor IX (Antihemophilic Factor B). Biochemistry 24:37363750

Zinoveiva N, Lassing C, Schams D, Besenfelder U, Wolf E, Muller S (1998) Stable production of human insulin-like growth factor 1 (IGF-1) in the milk of hemi- and homozygous transgenic rabbits over several generations. Transgenic Res 7:437-447 